Published in final edited form as:

Pituitary. 2015 April ; 18(2): 225-231. doi:10.1007/s11102-014-0624-3.

\title{
Silent Corticotroph Adenomas
}

\author{
Odelia Cooper ${ }^{1}$ \\ ${ }^{1}$ Pituitary Center, Cedars-Sinai Medical Center, 127 S. San Vicente Blvd., Suite A6600, Los \\ Angeles, CA 90048
}

\begin{abstract}
Purpose-Silent corticotroph adenomas (SCAs) comprise 20\% of all corticotroph adenomas and $3-19 \%$ of nonfunctioning adenomas (NFAs). As they do not manifest clinical or biochemical hypercortisolism, they are diagnosed after pathologic examination of resected tumor tissue demonstrates positive ACTH expression. While preoperative features are similar to those of NFAs, SCAs may have more cavernous sinus invasion. Further, patients with SCAs tend to have more frequent and earlier recurrences than those with NFAs, often necessitating multiple surgeries and other modalities of treatment. This article reviews the incidence, pathogenesis, and clinical behavior of SCAs.
\end{abstract}

Methods-A systematic literature review was performed using PubMed for information regarding silent corticotroph adenomas.

Results-Up to date findings regarding epidemiology, pathogenesis, pathology, clinical presentation, postoperative course, and management of patients with SCAs are presented.

Conclusions-This review highlights the necessity of rigorous monitoring for recurrences and hypopituitarism in patients with SCAs.

\section{Keywords}

silent corticotroph; cushing; pituitary adenoma; nonfunctioning

\section{Introduction}

Corticotroph adenomas ( $10 \%$ of pituitary tumors) are immunopositive for adrenocorticotrophic hormone (ACTH) and are associated with elevated circulating ACTH and cortisol levels leading to Cushing disease (CD) with features of hypercortisolism [31, $36]$. However, up to $20 \%$ of clinically inapparent corticotroph adenomas, known as silent corticotroph adenomas (SCAs), do not manifest biochemical or clinical evidence of hypercortisolism $[9,29,45]$. These adenomas are resected usually because of mass effects, and patients are followed post-operatively for persistent or recurrent mass growth with serial MRIs, and monitored for development of subsequent hypopituitarism [4, 10, 29, 50, 61].

Corresponding author and person to whom reprint requests should be addressed: Odelia Cooper, MD Pituitary Center Cedars-Sinai Medical Center 127 S. San Vicente Blvd., Suite A6600 Los Angeles, CA 90048 Phone: 310-423-2830 Fax: 310-423-2819 coopero@cshs.org.

Conflict of interest

The author declares that she has no conflict of interest. 
SCAs have consistently been shown to have a more aggressive postoperative course compared to nonfunctioning adenomas. This review presents the distinct pathogenesis of these tumors, their clinical behavior, and management.

\section{Epidemiology}

Pituitary tumors are monoclonal adenomas accounting for $\sim 15 \%$ of primary intracranial neoplasms [33] with prevalence of 2-9 per 10000 for clinically apparent adenomas [11, 13] and up to $25 \%$ for occult adenomas on autopsies [33]. Studies report the incidence of SCAs to be $3-19 \%$ of adenomas classified preoperatively as nonfunctioning adenomas $[4,8,16$, 20, 40, 63]. In the German Registry of Pituitary Tumors, 5.5\% of clinically silent adenomas were SCAs, with the sparsely granulated type II adenoma more common at $4.4 \%$ compared to the densely granulated type I adenoma at $1.1 \%$ [44].

\section{Pathology}

World Health Organization (WHO) guidelines classify SCAs as silent counterparts of functional corticotroph adenomas immunoreactive for ACTH [12] as they have similar expression of ACTH [24] and POMC [20]. Secretory granules of silent adenomas tend to be smaller than endocrine active adenomas [15]. Furthermore, electron microscopy studies have shown two morphologic variants of SCAs. To distinguish the two subtypes, periodic acid-Schiff staining may be helpful in addition to other features. Type I adenomas, which may comprise up to $68 \%$ of SCAs [20], are similar to functional corticotroph adenomas in that they are densely granulated basophilic tumors with abundant cytokeratin filaments, strongly PAS positive, stain diffusely for ACTH, and have higher Tpit expression. Subtype II adenomas are chromophobic, lack cytokeratin filaments, have scattered PAS staining, sparse ACTH staining, and lower Tpit expression [1][12, 16, 20]. In addition to corticotroph features, SCAs incorporate gonadotroph elements as evidenced by the presence of honeycomb Golgi [48, 64] and increased mitochondrial density [64]. In our series, two SCAs tested were categorized as SCA subtype II while the remainder incorporated elements of both corticotroph and gonadotroph adenomas. In particular, oncocytic transformation seen in three SCAs was typical of gonadotroph adenomas, whereas the granule pleomorphism and enlarged lysosomes/enigmatic bodies we observed in all the SCAs resembled corticotroph adenomas [10].

Expression of Ki-67 and p53 growth markers is inconsistent in SCAs [4, 40, 49, 63]. In one series, two recurrent cases had elevated MIB-1 index scores [2], and type I SCAs may have higher expression compared to type II SCAs [20]. Atypical adenomas, defined as elevated p53, Ki-67 above 3\%, and presence of mitoses [12], have been reported in 17-30\% of SCAs $[4,66]$ [40], while other series did not confirm these findings [43, 49, 63]. In our series, 4/13 had features of atypical adenomas (unpublished, Cooper O).

\section{Pathogenesis}

Several hypotheses have been proposed to explain the silence of these corticotroph adenomas. The first explanation may involve the role of tissue specific transcription factors which are useful markers for identifying pituitary tumor cytogenesis. Tpit, a tissue-specific regulator of POMC expression, is expressed in corticotrophs and melanotrophs [25, 27] and 
is a specific marker of POMC-producing cells in Cushing adenomas [59]. Another transcription factor NeuroD1 binds to the POMC promoter, activates POMC transcription [41], and contributes to the functional expression and differentiation of ACTH secreting adenomas as well as differentiation of nonfunctioning adenomas [26, 39]. SF-1 is localized to gonadotroph cells in nonfunctioning pituitary adenomas [66]. DAX-1, an orphan nuclear receptor, is also a cell-specific factor for gonadotroph cell differentiation [23] and is expressed in nonfunctioning adenomas [18]. SCAs have been shown by some groups to have similar Tpit expression to CD [20,58] while others demonstrate lower expression [10, 52]. In one series, despite variable expression, $P O M C$ and TPIT mRNA levels correlated positively in SCAs, similar to the pattern in Cushing macroadenomas [43]. In addition, SCAs have been shown to be immunoreactive for NeuroD1 as well as gonadotroph markers, DAX-1 and SF-1, in contradistinction to CD which are immunonegative for DAX-1 and SF-1. Finally, ACTH expression was demonstrated to co-localize with either LH or SF-1 in SCAs (Fig. 1). These findings suggest that SCAs may originate from a corticotrophgonadotroph progenitor cell [10].

A second mechanism may be from dysfunctional processing and biologic activity of pituitary hormones. In CD, plasma ACTH levels correlate with abundance of ACTHimmunopositive cells but not in SCAs [24]. Individual corticotroph cells in SCAs may secrete insufficient, or bio-inactive, ACTH molecules [24]. SCAs potentially derive from POMC producing cells in the vestigial pars intermedia of the human pituitary [17], and the clinical silence may be due to dysregulated POMC processing [37]. Prohormone convertase (PC) 1/3 transcripts, which cleave POMC to ACTH, indeed are downregulated in SCAs [51], with CD having 30-fold higher levels than SCAs, and 10-fold higher levels observed in type I compared to type II SCAs which further suggest a defect in conversion of POMC to ACTH in SCAs [20].

Finally, cell motility and migration may have a role in the pathogenesis of SCAs. One study demonstrated higher $\beta 1$-integrin and osteopontin expression and lower MMP-1 and FGFR4 immunoreactivity in SCAs compared to NFAs [34]. Galectin-3, which is involved in cell growth and differentiation, cell adhesion, and tumor progression, is more abundantly expressed in CD compared to SCAs [21, 43, 55].

On rare occasions, SCAs transform to active $\mathrm{CD}$. The level of ACTH may be too low when the adenoma is in the clinically silent stage and then becomes higher when it converts to active clinical CD. It is possible as well that in the clinically active stage, a different form of ACTH is secreted, or there may be cyclical production of ACTH or changes occurring in processing enzymes or POMC mRNA [1, 28, 50, 57].

\section{Clinical course}

SCAs are usually diagnosed pre-operatively as nonfunctioning adenomas, and the definitive diagnosis of SCA is determined retrospectively after pathological examination of resected tumor tissue. In some series, there was a female preponderance in SCAs compared to nonfunctioning adenomas [30, 52, 61, 63], but not in others [4, 5, 40, 50, 61]. Patients frequently present with tumor mass effects, including headaches, visual disturbances, and hypopituitarism [50]. Alternatively, SCAs may be incidentally diagnosed when brain MRIs 
are performed for unrelated reasons [30]. SCAs therefore generally present as non-secreting macroadenomas, and pre-operative laboratory studies reveal normal cortisol levels and normal to low LH/FSH and sex steroid and normal to slightly elevated prolactin (PRL) levels $[4,30,45,61]$. Some SCAs may have elevated ACTH levels with normal cortisol levels $[43,50,52,56,61]$.

A number of studies have investigated whether SCAs have a more aggressive presentation (Table 1). Up to $60 \%$ of SCAs manifest with preoperative hypopituitarism, similar to rates observed in nonfunctioning adenomas $[9,10,20,50,61]$ though one series reported rates as high as $76 \%$ in SCAs ( $\mathrm{n}=33$ ) compared to $50 \%$ in NFAs $(\mathrm{n}=126)$ [19]. Radiologic features are generally similar between SCAs and NFAs [9, 10, 19, 43] though cavernous sinus invasion may be more prevalent in SCAs than in nonfunctioning adenomas [4, 20, 49, 50, 63]. One group identified multiple microcysts $(<3 \mathrm{~mm})$ of high intensity signal on $\mathrm{T} 2$ weighted images in $77 \%$ of SCAs compared $21 \%$ in CD and $5 \%$ of NFAs, and macrocysts in $23 \%$ of SCAs [7]. Further, SCAs may have higher rates of intratumoral hemorrhage [9].

On the other hand, the postoperative course in SCAs tends to differ from NFAs. New onset postoperative hypopituitarism has been reported in up to half of SCAs $[10,50,61]$ including postoperative adrenal insufficiency [10, 29, 42, 45, 46, 61] though other studies did not confirm these differences $[9,19]$. While SCA recurrence rates of up to $60 \%$ have been documented $[4,5,10,19,50,61]$, these rates do not differ from those observed with nonfunctioning adenomas $[5,8,63]$. We demonstrated that SCAs recur five years earlier than NFAs [10], and de novo recurrences were seen more frequently in patients with SCAs [10]. Further, SCAs frequently have multiple recurrences compared to NFAs [8, 20]. SCA subtype may predict recurrence as shown in a series of 75 SCAs, in which the 3 year tumor progression rate was $34 \%$ for type I and $10 \%$ in type II adenomas compared to $6 \%$ for NFAs [20].

A number of individual cases of SCAs were reported to transform to symptomatic functioning Cushing Disease, notably after receiving radiotherapy [3, 4, 6, 14, 32, 60, 64]. However, in large series of SCAs, 2 groups each reported only 1 case transforming to biochemical Cushing disease but without clinical stigmata [19, 61]. In the series of 75 SCAs, three type I SCAs developed CD 7 years on average after initial SCA diagnosis [20]. One case of an SCA that later converted to CD occurred in an atypical type II adenoma [42].

\section{Management}

SCAs are primarily treated with surgery, but as they tend to recur, additional modalities of therapy have been investigated.

Use of stereotactic radiosurgery (SRS) may be an adjuvant therapy for SCAs. One study compared outcomes in 34 SCAs to 70 NFAs who received SRS. Tumor control was attained in $62 \%$ of SCAs compared to $93 \%$ in NFAs, and at 8 years, progression free survival was $31 \%$ compared to $87 \%$, respectively. However, the dose used in this study may have been a factor in the observed response rate ( $<17 \mathrm{~Gy}$ was associated with poorer response) [62]. 
Another potential therapy may be somatostatin analogs. SCAs were reported to have 200fold higher somatostatin receptor (SSTR) 1 mRNA levels than NFAs and 17-fold higher than CD, higher SSTR2 mRNA levels than CD, and lower SSTR5 mRNA levels than CD [53]. Anecdotally, we treated a patient with an aggressive SCA with pasireotide and temozolomide. He had a 16 year history of an SCA for which he had undergone 2 resections, gamma knife radiosurgery and then radiation therapy for further growth of the residual tumor. Seven months after the $2^{\text {nd }}$ surgery, the patient presented with marked enlargement of the right cavernous portion of the tumor concomitant with complete right ophthalmoplegia. While there were no Cushingoid stigmata, his 24 hour urine free cortisol (UFC) levels were elevated up to $482 \mathrm{mcg}$ with ACTH levels up to $121 \mathrm{pg} / \mathrm{mL}$. We started the patient on temozolomide and pasireotide $600 \mathrm{mcg}$ twice a day. Over the next month, the UFC normalized, ACTH levels decreased, and the tumor size reduced. He is currently maintained on pasireotide after completing six cycles of temozolomide (author's personal experience).

Temozolomide has been explored as a possible chemotherapy for SCAs as they have low or absent MGMT immunostaining compared to Cushing disease adenomas [47].

Approximately 20 corticotroph tumors have been treated with temozolomide in the literature, 3 of which were SCA carcinomas which did not maintain response to temozolomide [22, 35, 54]. One group reported use of a combined regimen of temozolomide and capecitabine in a patient with an SCA which did lead to a reduction in tumor size [65].

Finally, anti-VEGF therapy may be another potential treatment. In one case of a type II SCA that progressed to carcinoma, the patient was treated with bevacizumab which stabilized the disease for over two years [38].

\section{Conclusion}

In summary, SCAs are a biologically and pathologically distinct subtype of pituitary adenomas. The bulk of evidence indicates that SCAs are an aggressive variant of both corticotroph and nonfunctioning adenomas. While preoperatively, they may present as NFAs, they need to be monitored closely in the postoperative period for development of hypopituitarism and for more frequent and earlier recurrences, and more rarely for possible transformation to $\mathrm{CD}$. Multimodal therapy may be necessary to adequately manage patients who recur, and larger clinical trials will hopefully demonstrate more effective medications.

\section{Acknowledgements}

This work is supported by NIH grant K23DK085148 (O. Cooper).

\section{References}

1. Abe T, Ludecke DK, Saeger W. Clinically nonsecreting pituitary adenomas in childhood and adolescence. Neurosurgery. 1998; 42:744-750. discussion 750-741. [PubMed: 9574638]

2. Alahmadi H, Lee D, Wilson JR, Hayhurst C, Mete O, Gentili F, Asa SL, Zadeh G. Clinical features of silent corticotroph adenomas. Acta Neurochir (Wien). 2012; 154:1493-1498. Doi 10.1007/ s00701-012-1378-1. [PubMed: 22619024] 
3. Ambrosi B, Colombo P, Bochicchio D, Bassetti M, Masini B, Faglia G. The silent corticotropinoma: is clinical diagnosis possible? J Endocrinol Invest. 1992; 15:443-452. [PubMed: 1328350]

4. Baldeweg SE, Pollock JR, Powell M, Ahlquist J. A spectrum of behaviour in silent corticotroph pituitary adenomas. Br J Neurosurg. 2005; 19:38-42. Doi 10.1080/02688690500081230. [PubMed: 16147581]

5. Bradley KJ, Wass JA, Turner HE. Non-functioning pituitary adenomas with positive immunoreactivity for ACTH behave more aggressively than ACTH immunonegative tumours but do not recur more frequently. Clin Endocrinol (Oxf). 2003; 58:59-64. Doi 1674 [pii]. [PubMed: 12519413]

6. Brown RL, Wollman R, Weiss RE. Transformation of a pituitary macroadenoma into to a corticotropin-secreting carcinoma over 16 years. Endocr Pract. 2007; 13:463-471. Doi 10.4158/EP. 13.5.463. [PubMed: 17872347]

7. Cazabat L, Dupuy M, Boulin A, Bernier M, Baussart B, Foubert L, Raffin-Sanson ML, Caron P, Bertherat J, Gaillard S. Silent, but not unseen: multimicrocystic aspect on T2-weighted MRI in silent corticotroph adenomas. Clin Endocrinol (Oxf). 2014; 81:566-572. Doi 10.1111/cen.12443. [PubMed: 24601912]

8. Cho HY, Cho SW, Kim SW, Shin CS, Park KS, Kim SY. Silent corticotroph adenomas have unique recurrence characteristics as compared with other nonfunctioning pituitary adenomas. Clin Endocrinol (Oxf). 2009 Doi CEN3673 [pii] 10.1111/j.1365-2265.2009.03673.x [doi].

9. Cho HY, Cho SW, Kim SW, Shin CS, Park KS, Kim SY. Silent corticotroph adenomas have unique recurrence characteristics compared with other nonfunctioning pituitary adenomas. Clin Endocrinol (Oxf). 2010; 72:648-653. Doi 10.1111/j.1365-2265.2009.03673.x. [PubMed: 19650787]

10. Cooper O, Ben-Shlomo A, Bonert V, Bannykh S, Mirocha J, Melmed S. Silent corticogonadotroph adenomas: clinical and cellular characteristics and long-term outcomes. Horm Cancer. 2010; 1:8092. Doi 10.1007/s12672-010-0014-x. [PubMed: 20717480]

11. Daly AF, Rixhon M, Adam C, Dempegioti A, Tichomirowa MA, Beckers A. High prevalence of pituitary adenomas: a cross-sectional study in the province of Liege, Belgium. J Clin Endocrinol Metab. 2006; 91:4769-4775. Doi 10.1210/jc.2006-1668. [PubMed: 16968795]

12. DeLellis, RA.; Lloyd, RV.; Heitz, PU.; Eng, C. Pathology and Genetics of tumors of Endocrine Organs. In: PU, K.; LH, S., editors. World Health Organization Classification of Tumours. IARC Press; City: 2004.

13. Fernandez A, Karavitaki N, Wass JA. Prevalence of pituitary adenomas: a community-based, cross-sectional study in Banbury (Oxfordshire, UK). Clin Endocrinol (Oxf). 2010; 72:377-382. Doi 10.1111/j.1365-2265.2009.03667.x. [PubMed: 19650784]

14. Gogel EL, Salber PR, Tyrrell JB, Rosenblum ML, Findling JW. Cushing's disease in a patient with a 'nonfunctioning' pituitary tumor. Spontaneous development and remission. Arch Intern Med. 1983; 143:1040-1042. [PubMed: 6089681]

15. Holck S, Wewer UM, Albrechtsen R. Heterogeneity of secretory granules of silent pituitary adenomas. Mod Pathol. 1988; 1:212-215. [PubMed: 3237702]

16. Horvath E, Kovacs K, Killinger DW, Smyth HS, Platts ME, Singer W. Silent corticotropic adenomas of the human pituitary gland: a histologic, immunocytologic, and ultrastructural study. Am J Pathol. 1980; 98:617-638. [PubMed: 6244736]

17. Horvath E, Kovacs K, Lloyd RV. Pars intermedia of the human pituitary revisited: morphologic aspects and frequency of hyperplasia of POMC-peptide immunoreactive cells. Endocrine Pathology. 1999; 10:55-64.

18. Ikuyama S, Mu Y-M, Ohe K, Nakagaki H, Fukushima T, Takayanagi R, Nawata H. Expression of an orphan nuclear receptor DAX-1 in human pituitary adenomas. Clin Endocrinol (Oxf). 1998; 48:647-654. [PubMed: 9666878]

19. Ioachimescu AG, Eiland L, Chhabra VS, Mastrogianakis GM, Schniederjan MJ, Brat D, Pileggi AV, Oyesiku NM. Silent corticotroph adenomas: Emory University cohort and comparison with ACTH-negative nonfunctioning pituitary adenomas. Neurosurgery. 2012; 71:296-303. discussion 304 Doi 10.1227/NEU.0b013e318257c1f0. [PubMed: 22517250] 
20. Jahangiri A, Wagner JR, Pekmezci M, Hiniker A, Chang EF, Kunwar S, Blevins L, Aghi MK. A comprehensive long-term retrospective analysis of silent corticotrophic adenomas vs hormonenegative adenomas. Neurosurgery. 2013; 73:8-17. discussion 17-18 Doi 10.1227/01.neu. 0000429858.96652.1e. [PubMed: 23685641]

21. Jin L, Riss D, Ruebel K, Kajita S, Scheithauer BW, Horvath E, Kovacs K, Lloyd RV. Galectin-3 Expression in Functioning and Silent ACTH-Producing Adenomas. Endocr Pathol. 2005; 16:107114. Doi EP:16:2:107 [pii]. [PubMed: 16199895]

22. Jouanneau E, Wierinckx A, Ducray F, Favrel V, Borson-Chazot F, Honnorat J, Trouillas J, Raverot G. New targeted therapies in pituitary carcinoma resistant to temozolomide. Pituitary. 2012; 15:37-43. Doi 10.1007/s11102-011-0341-0. [PubMed: 21858654]

23. Kawabe K, Shikayama T, Tsuboi H, Oka S, Oba K, Yanase T, Nawata H, Morohashi K-i. Dax-1 as one of the target genes of Ad4BP/SF-1. Mol Endocrinol. 1999; 13:1267-1284. [PubMed: 10446902]

24. Kojima Y, Suzuki S, Yamamura K, Ohhashi G, Yamamoto I. Comparison of ACTH secretion in Cushing's adenoma and clinically silent corticotroph adenoma by cell immunoblot assay. Endocr J. 2002; 49:285-292. [PubMed: 12201210]

25. Lamolet B, Pulichino A-M, Lamonerie T, Gauthier Y, Brue T, Enjalbert A, Drouin J. A pituitary cell-restricted $\mathrm{T}$ box factor, Tpit, activates POMC transcription in cooperation with Pitx homeoproteins. Cell. 2001; 104:849-859. Doi S0092-8674(01)00282-3 [pii]. [PubMed: 11290323]

26. Lavoie P-L, Budry L, Balsalobre A, Drouin J. Developmental dependence on NurRE and EboxNeuro for expression of pituitary proopiomelanocortin. Mol Endocrinol. 2008; 22:16471657. Doi me.2007-0567 [pii] 10.1210/me.2007-0567 [doi]. [PubMed: 18388149]

27. Liu J, Lin C, Gleiberman A, Ohgi KA, Herman T, Huang H-P, Tsai M-J, Rosenfeld MG. Tbx19, a tissue-selective regulator of POMC gene expression. Proc Natl Acad Sci U S A. 2001; 98:86748679. [PubMed: 11447259]

28. Lloyd RV, Fields K, Jin L, Horvath E, Kovacs K. Analysis of endocrine active and clinically silent corticotropic adenomas by in situ hybridization. Am J Pathol. 1990; 137:479-488. [PubMed: 2167013]

29. Lopez JA, Kleinschmidt-Demasters Bk B, Sze CI, Woodmansee WW, Lillehei KO. Silent corticotroph adenomas: further clinical and pathological observations. Hum Pathol. 2004; 35:1137-1147. [PubMed: 15343517]

30. Lopez JA, Kleinschmidt-Demasters Bk Bk, Sze C-I, Woodmansee WW, Lillehei KO. Silent corticotroph adenomas: further clinical and pathological observations. Hum Pathol. 2004; 35:1137-1147. Doi S0046817704003235 [pii]. [PubMed: 15343517]

31. Meier CA, Biller BM. Clinical and biochemical evaluation of Cushing's syndrome. Endocrinol Metab Clin North Am. 1997; 26:741-762. [PubMed: 9429858]

32. Melcescu E, Gannon AW, Parent AD, Fratkin JF, Nicholas WC, Koch CA, Galhom A. Silent or Subclinical Corticotroph Pituitary Macroadenoma Transforming Into Cushing Disease: 11-Year Follow-up. Neurosurgery. 2013; 72:E144-146. Doi 10.1227/NEU.0b013e3182750850. [PubMed: 23037824]

33. Melmed S. Mechanisms for pituitary tumorigenesis: the plastic pituitary. J Clin Invest. 2003; 112:1603-1618. [PubMed: 14660734]

34. Mete O, Hayhurst C, Alahmadi H, Monsalves E, Gucer H, Gentili F, Ezzat S, Asa SL, Zadeh G. The role of mediators of cell invasiveness, motility, and migration in the pathogenesis of silent corticotroph adenomas. Endocr Pathol. 2013; 24:191-198. Doi 10.1007/s12022-013-9270-y. [PubMed: 24091601]

35. Moshkin O, Syro LV, Scheithauer BW, Ortiz LD, Fadul CE, Uribe H, Gonzalez R, Cusimano M, Horvath E, Rotondo F. Aggressive silent corticotroph adenoma progressing to pituitary carcinoma: the role of temozolomide therapy. Hormones (Athens). 2011; 10:162-167. [PubMed: 21724542]

36. Nieman LK, Biller BMK, Findling JW, Newell-Price J, Savage MO, Stewart PM, Montori VM. The diagnosis of Cushing's syndrome: an Endocrine Society Clinical Practice Guideline. J Clin Endocrinol Metab. 2008; 93:1526-1540. Doi jc.2008-0125 [pii] 10.1210/jc.2008-0125 [doi]. [PubMed: 18334580] 
37. Ohta S, Nishizawa S, Oki Y, Yokoyama T, Namba H. Significance of absent prohormone convertase $1 / 3$ in inducing clinically silent corticotroph pituitary adenoma of subtype I-immunohistochemical study. Pituitary. 2002; 5:221-223. [PubMed: 14558669]

38. Ortiz LD, Syro LV, Scheithauer BW, Ersen A, Uribe H, Fadul CE, Rotondo F, Horvath E, Kovacs K. Anti-VEGF therapy in pituitary carcinoma. Pituitary. 2012; 15:445-449. Doi 10.1007/ s11102-011-0346-8. [PubMed: 21918831]

39. Oyama K, Sanno N, Teramoto A, Osamura RY. Expression of neuro D1 in human normal pituitaries and pituitary adenomas. Mod Pathol. 2001; 14:892-899. [PubMed: 11557786]

40. Pawlikowski M, Kunert-Radek J, Radek M. “Silent” corticotropinoma. Neuro Endocrinol Lett. 2008; 29:347-350. Doi NEL290308A10 [pii]. [PubMed: 18580839]

41. Poulin G, Turgeon B, Drouin J. NeuroD1/beta2 contributes to cell-specific transcription of the proopiomelanocortin gene. Mol Cell Biol. 1997; 17:6673-6682. [PubMed: 9343431]

42. Psaras T, Honegger J, Buslei R, Saeger W, Klein D, Capper D, Meyermann R, Mittelbronn M. Atypical type II silent corticotrophic adenoma developing into Cushing's disease upon second recurrence. Exp Clin Endocrinol Diabetes. 2007; 115:610-615. Doi 10.1055/s-2007-984437. [PubMed: 17943697]

43. Raverot G, Wierinckx A, Jouanneau E, Auger C, Borson-Chazot F, Lachuer J, Pugeat M, Trouillas J. Clinical, hormonal and molecular characterization of pituitary ACTH adenomas without (silent corticotroph adenomas) and with Cushing's disease. Eur J Endocrinol. 2010; 163:35-43. Doi 10.1530/eje-10-0076. [PubMed: 20385723]

44. Saeger W, Ludecke DK, Buchfelder M, Fahlbusch R, Quabbe HJ, Petersenn S. Pathohistological classification of pituitary tumors: 10 years of experience with the German Pituitary Tumor Registry. Eur J Endocrinol. 2007; 156:203-216. Doi 10.1530/eje.1.02326. [PubMed: 17287410]

45. Sahli R, Christ ER, Seiler R, Kappeler A, Vajtai I. Clinicopathologic correlations of silent corticotroph adenomas of the pituitary: report of four cases and literature review. Pathol Res Pract. 2006; 202:457-464. Doi 10.1016/j.prp.2006.01.007. [PubMed: 16497445]

46. Sakaguchi H, Koshiyama H, Sano T, Inoue D, Hashimoto N, Aoki N, Nakao K. A case of nonfunctioning pituitary adenoma resembling so-called silent corticotroph adenoma. Endocr J. 1997; 44:329-333. [PubMed: 9228470]

47. Salehi F, Scheithauer BW, Kovacs K, Horvath E, Syro LV, Sharma S, Manoranjan B, Cusimano M. O-6-methylguanine-DNA methyltransferase (MGMT) immunohistochemical expression in pituitary corticotroph adenomas. Neurosurgery. 2012; 70:491-496. discussion 496 Doi 10.1227/ NEU.0b013e318230ac63. [PubMed: 21822153]

48. Sano T, Kovacs K, Asa SL, Yamada S, Sanno N, Yokoyama S, Takami H. Pituitary adenoma with "honeycomb Golgi" appearance showing a phenotypic change at recurrence from clinically nonfunctioning to typical Cushing disease. Endocr Pathol. 2002; 13:125-130. [PubMed: 12165660]

49. Scheithauer BW, Gaffey TA, Lloyd RV, Sebo TJ, Kovacs KT, Horvath E, Yapicier O, Young WF Jr. Meyer FB, Kuroki T. Pathobiology of pituitary adenomas and carcinomas. Neurosurgery. 2006; 59:341-353. discussion 341-353 Doi 10.1227/01.NEU.0000223437.51435.6E [doi] 00006123-200608000-00016 [pii]. [PubMed: 16883174]

50. Scheithauer BW, Jaap AJ, Horvath E, Kovacs K, Lloyd RV, Meyer FB, Laws ER Jr. Young WF Jr. Clinically silent corticotroph tumors of the pituitary gland. Neurosurgery. 2000; 47:723-729. discussion 729-730. [PubMed: 10981760]

51. Tateno T, Izumiyama H, Doi M, Akashi T, Ohno K, Hirata Y. Defective expression of prohormone convertase 1/3 in silent corticotroph adenoma. Endocr J. 2007; 54:777-782. Doi JST.JSTAGE/ endocrj/K07-059 [pii]. [PubMed: 17917309]

52. Tateno T, Izumiyama H, Doi M, Yoshimoto T, Shichiri M, Inoshita N, Oyama K, Yamada S, Hirata Y. Differential gene expression in ACTH -secreting and non-functioning pituitary tumors. Eur J Endocrinol. 2007; 157:717-724. Doi 157/6/717 [pii] 10.1530/EJE-07-0428 [doi]. [PubMed: 18057378]

53. Tateno T, Kato M, Tani Y, Oyama K, Yamada S, Hirata Y. Differential expression of somatostatin and dopamine receptor subtype genes in adrenocorticotropin (ACTH)-secreting pituitary tumors and silent corticotroph adenomas. Endocr J. 2009; 56:579-584. [PubMed: 19318729] 
54. Thearle MS, Freda PU, Bruce JN, Isaacson SR, Lee Y, Fine RL. Temozolomide (Temodar(R)) and capecitabine $(\mathrm{Xeloda}(\mathrm{R}))$ treatment of an aggressive corticotroph pituitary tumor. Pituitary. 2011; 14:418-424. Doi 10.1007/s11102-009-0211-1. [PubMed: 19960369]

55. Thodou E, Argyrakos T, Kontogeorgos G. Galectin-3 as a marker distinguishing functioning from silent corticotroph adenomas. Hormones (Athens). 2007; 6:227-232. [PubMed: 17724007]

56. Tourniaire J. [The so-called silent corticotropic pituitary adenoma]. Presse Med. 1991; 20:197198. [PubMed: 1848932]

57. Ueyama T, Tamaki N, Kondoh T, Kurata H. Large and invasive silent corticotroph-cell adenoma with elevated serum ACTH: a case report. Surg Neurol. 1998; 50:30-31. discussion 32 Doi S0090-3019(98)00013-5 [pii]. [PubMed: 9657490]

58. Vallette-Kasic S, Figarella-Branger D, Grino M, Pulichino A-M, Dufour H, Grisoli F, Enjalbert A, Drouin J, Brue T. Differential regulation of proopiomelanocortin and pituitary-restricted transcription factor (TPIT), a new marker of normal and adenomatous human corticotrophs. J Clin Endocrinol Metab. 2003; 88:3050-3056. [PubMed: 12843142]

59. Vallette-Kasic S, Figarella-Branger D, Grino M, Pulichino AM, Dufour H, Grisoli F, Enjalbert A, Drouin J, Brue T. Differential regulation of proopiomelanocortin and pituitary-restricted transcription factor (TPIT), a new marker of normal and adenomatous human corticotrophs. J Clin Endocrinol Metab. 2003; 88:3050-3056. [PubMed: 12843142]

60. Vaughan NJ, Laroche CM, Goodman I, Davies MJ, Jenkins JS. Pituitary Cushing's disease arising from a previously non-functional corticotrophic chromophobe adenoma. Clin Endocrinol (Oxf). 1985; 22:147-153. [PubMed: 2985300]

61. Webb KM, Laurent JJ, Okonkwo DO, Lopes MB, Vance ML, Laws ER Jr. Clinical characteristics of silent corticotrophic adenomas and creation of an internet-accessible database to facilitate their multi-institutional study. Neurosurgery. 2003; 53:1076-1084. discussion 1084-1075. [PubMed: 14580274]

62. Xu Z, Ellis S, Lee CC, Starke RM, Schlesinger D, Lee Vance M, Lopes MB, Sheehan J. Silent Corticotroph Adenomas After Stereotactic Radiosurgery: A Case-Control Study. International journal of radiation oncology, biology, physics. 2014 Doi 10.1016/j.ijrobp.2014.07.013.

63. Yamada S, Ohyama K, Taguchi M, Takeshita A, Morita K, Takano K, Sano T. A study of the correlation between morphological findings and biological activities in clinically nonfunctioning pituitary adenomas. Neurosurgery. 2007; 61:580-584. discussion 584-585 Doi 10.1227/01.NEU. 0000290906.53685.79 [doi] 00006123-200709000-00020 [pii]. [PubMed: 17881972]

64. Yokoyama S, Kawahara Y, Sano T, Nakayama M, Kitajima S-i, Kuratsu J-i. A case of nonfunctioning pituitary adenoma with Cushing's syndrome upon recurrence. Neuropathology. 2001; 21:288-293. [PubMed: 11837535]

65. Zacharia BE, Gulati AP, Bruce JN, Carminucci AS, Wardlaw SL, Siegelin M, Remotti H, Lignelli A, Fine RL. High response rates and prolonged survival in patients with corticotroph pituitary tumors and refractory Cushing disease from capecitabine and temozolomide (CAPTEM): a case series. Neurosurgery. 2014; 74:E447-455. discussion E455 Doi 10.1227/NEU. 0000000000000251. [PubMed: 24226425]

66. Zada G, Woodmansee WW, Ramkissoon S, Amadio J, Nose V, Laws ER Jr. Atypical pituitary adenomas: incidence, clinical characteristics, and implications. J Neurosurg. 2011; 114:336-344. Doi 10.3171/2010.8.JNS10290. [PubMed: 20868211] 

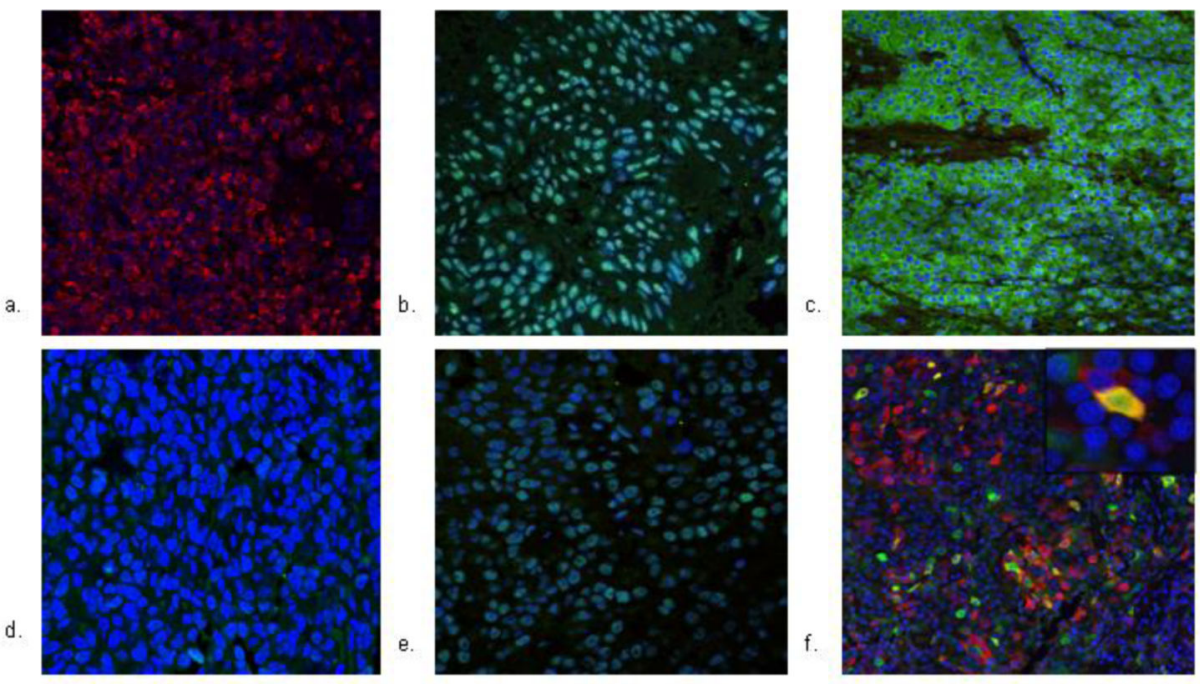

Fig. 1.

Demonstration of dual corticotroph (assessed with ACTH, Tpit, and NeuroD1 markers) and gonadotroph (assessed with LH, DAX-1, and SF-1 markers) lineage in an SCA.

Fluorescence immunohistochemistry of corticotroph markers ACTH, Tpit, NeuroD1, LH, DAX-1, and SF-1 were performed in a silent corticotroph adenoma. Tumor was fixed in $10 \%$ formalin, paraffin embedded, and stained with primary antibodies, with Alexa 488 secondary antibodies and visualized with confocal immunofluorescence microscopy at 20-40 x magnification. Tumor is (a) ACTH positive (b) NeuroD1 positive (c) SF-1 positive (d) Tpit negative, and (e) DAX-1 positive. (f) Tumor exhibits co-localization of ACTH and LH, showing potential derivation of SCAs from dual corticotroph-gonadotroph line. Portion of the field enlarged for detail (100 x) highlights the co-localization in a cell. [10] 


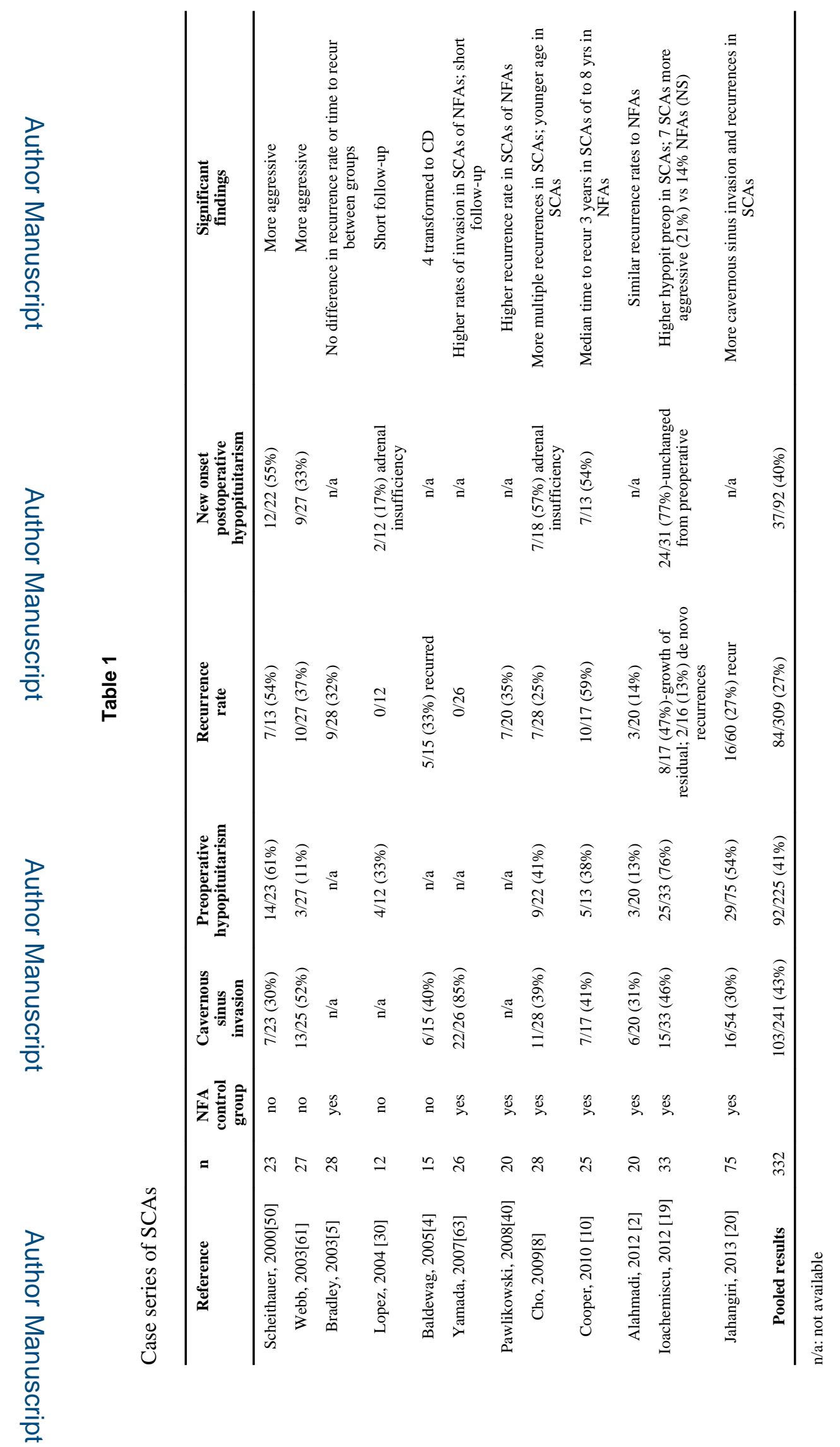

Pituitary. Author manuscript; available in PMC 2016 April 01. 